\title{
Geological Structure and Geodynamical Development of Kazakhstan Territory
}

\author{
Adilkhan Baibatsha \\ Geology department \\ Kazakh National Research Technical University named after K.I.Satpayev KazNRTU \\ Almaty, Kazakhstan \\ baibatsha48@mail.ru
}

\begin{abstract}
According to the seismic tomography, the lithosphere formation of Kazakhstan has a plume origin. Kazakhstan in the Paleozoic was a separate continent and consisted of three concentric rings of bounded geometry sutures. The rings under the active influence of mantle plume made vertical movement and their axes made horizontal movement. The development of variously oriented lineaments led to the formation of clumpy-block structure. The modern structure of Kazakhstan was formed during the interaction with Europe, Siberia and southern continents during the Paleozoic-Cenozoic.
\end{abstract}

Keywords-Kazakhstan, the crust, deep structure, continents and oceans, mantle plumes, ring structures, geological formations.

\section{INTRODUCTION}

The end of the XX century was marked by a dramatic breakthrough in understanding of the deep Earth's interior based on well-designed studies, including the subsurface geophysical studies, ultra-deep continental and oceanic drilling, as well as instrumental studies at the Earth's surface and from the space.

New data on the deep structure of the crust and upper mantle of continents form complex studies of the international system geo-traverses were collected. Some of them have been laid through the territory of Kazakhstan. On their basis, the models of the lithosphere to a depth of 100-200 km in the Republic were established, which revealed non-uniform-block structure of the upper mantle. At a depth of about $200 \mathrm{~km}$, the mantle electrical resistance is dramatically reduced, which presumably is linked with the rise of the roof of the asthenospheric layer. The structures of the crust in some cases are continuing in the upper mantle. Asthenosphere in the geosuture areas rise to the level of $80-100 \mathrm{~km}$, and asthenolith penetrate above the Moho in the crust [7-9].

\section{BRIEF GEOLOGICAL History OF DEVELOPMENT OF KAZAKHSTAN}

According to various estimations, between half and three quarters of the modern continental crust of Kazakhstan was formed in the Early Precambrian to the beginning of the late Proterozoic. As a result of atrophy and the closure of the Early Proterozoic deep basin, this crust in the Paleoproterozoic was shrunk into a single supercontinent called Pangaea I or
Megageya, unlike Late Paleozoic-Early Mesozoic Pangaea II (firstly isolated by A. Wegener). On the supercontinent, the paleomagnetic data indicated that the similarity of the curves of apparent migration of the magnetic poles that define different continents.

Grenville Orogeny played an appreciable role in Kazakhstan («Issedonic Orogeny»). It accomplished the formation of the foundation of neighboring Siberian and East European ancient platforms. Neoproterozoic, especially its second half, since 850 million years ago, is one of the most critical periods in the Earth's history (the era of disintegration of Pangaea I and early disclosure of the Paleozoic oceans). With the beginning of Proto-Tethys mobile belt, Pangaea I was split into two parts, original part (Rodinia) in the north and Gondwana in the south. But these two continental masses soon, if not simultaneously, have also been split. It is assumed that the splitting of Rodinia formed the independent continents of Siberia and Kazakhstan (V. E. Khain, the Kazakh continent), Cathaysia et al [16]. Already in the Neoproterozoic Kazakhstan began to exist independently [18] (Fig. 1).

Fig. 1. Paleogeodynamic reconstruction for the 850-800 Ma interval $[18]$

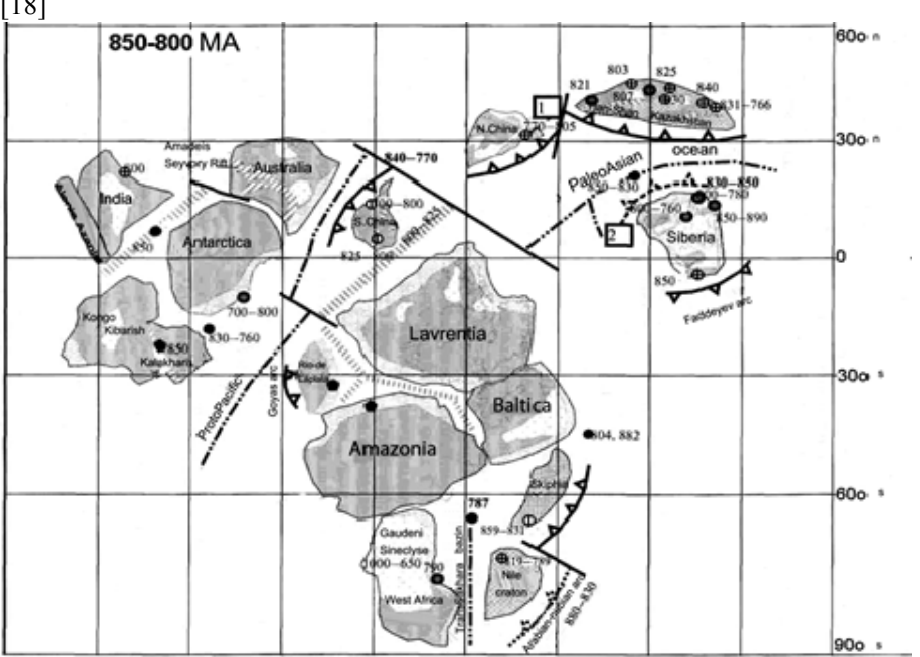

In contrast to Gondwana, where the dominant trend is the unification, other fragments of Proterozoic Pangaea I has been 
scattered since the beginning of the Cambrian as a result of the appearance of Neogenic Oceanic basins, one of them is the Proto-Atlantic ocean or the Japetus ocean, another PaleoAsiatic ocean, which divided Eastern Europe from East Siberia, as well as, East Siberia from the Roman and Chinese-Korean continents, the third ocean is the Mediterranean sea or PaleoTethys, which surrounded the Gondwana from the north and separated it from North America, Eastern Europe, the Roman block and the Chinese-Korean continents. These oceans are interconnected in between and with Paleopacific Ocean.

In the early Cambrian, Eastern Europe and Siberia were in the Southern Hemisphere. The first main part in the temperate zone is Siberia, which was located in the tropical area. Chinese-Korean continent was located in mid-latitude of the Northern Hemisphere. In addition to the major continents, within the Neogenic Oceans were existed smaller continental masses, partially separated from the main branches of the major continents and oceans. These include, in particular, Kazakhstan (Kazakh), Tuva-Mongolian, Barguzin-Vitimsky, central Mongolian arrays in the Paleo-Asiatic Ocean.

The ophiolites mobile belts (products of Paleo-Oceanic floor spreading) are widespread in particular in Kazakhstan, the Altai-Sayan region, northern Mongolia and in some other regions. The width of the Paleo-Asiatic Ocean in this period is estimated at 3,000 km.

In the Early Ordovician, Gondwana supercontinent was shifted to the south and from its northern margin was broken away into micro-continents. This was associated with a disclosure of deep basin with oceanic crust type in the northern part of the European segment (Paleo-Tethys), this basin is often distinguished as a separate ocean Reikum (in Greek mythology, Rhea - the daughter of Zeus). In the Early Ordovician, the Ural deep-basin, which was a suburban basin of the Paleo-Asiatic Ocean, was greatly expanded.

In the Middle Ordovician, the Japetus, Paleo-Tethys, PaleoAsiatic and Arctic intercontinental oceanic basins reached the maximum width. In their active margins have continued to develop the volcanic arc, this process is manifested in Kazakhstan (in geosuture zones), the Altai-Sayan region and in the Urals.

Takonic phase of tectogenesis was considered an area of intense tectonic deformation in central Kazakhstan and North Tien Shan. The cause of deformation is the collision of continental blocks of the Middle Tien Shan microcontinent and fragment of the Roman continent with the larger Kazakh microcontinent. Here the widespread distribution of granites is associated with this phase of tectogenesis.

The situation in the mobile belts in some places has undergone significant changes due to takonic orogeny. Thus, this greatly expanded the contours of the Kazakh continent.

In the early Silurian, an extension of marine basins is observed in the northern continents. All these continents were arranged in the equatorial and tropical zones; Siberia to the north of the equator, Eastern Europe to the south and the position of the Kazakh continent remained in the same position (Fig. 2).
Within the Ob-Zaisan and Zhongar-Balkhash systems, which are the axial part of the Paleo-Asiatic Ocean, underwater eruption in deep-water conditions were occurred, and in the intervals between these eruptions, shale and siliceous complexes with a several kilometers thickness, were formed, while on the continental slope terrigenous sediments up to 10 $\mathrm{km}$ thickness were formed.

In Kazakhstan Orogenic region, the area of residual marine basin was decreased, while the uplanded and mountainous regions were expanded. In the marine depression in the northwestern part of the Balkhash and Ridge Ketmen regions was located a reef massif and a limited bay in which very thickened conglomerates and coarse-grained sandstone were formed. The thickness of clastic formations in the Central and Southern Kazakhstan depression exceed $5 \mathrm{~km}$.

Fig. 2. The positions of continents and oceans and climate zonation in the Silurian period on Palinspastic basis [13]: EE-Eastern Europe; S-Siberia; Ch-K-China-Korean;

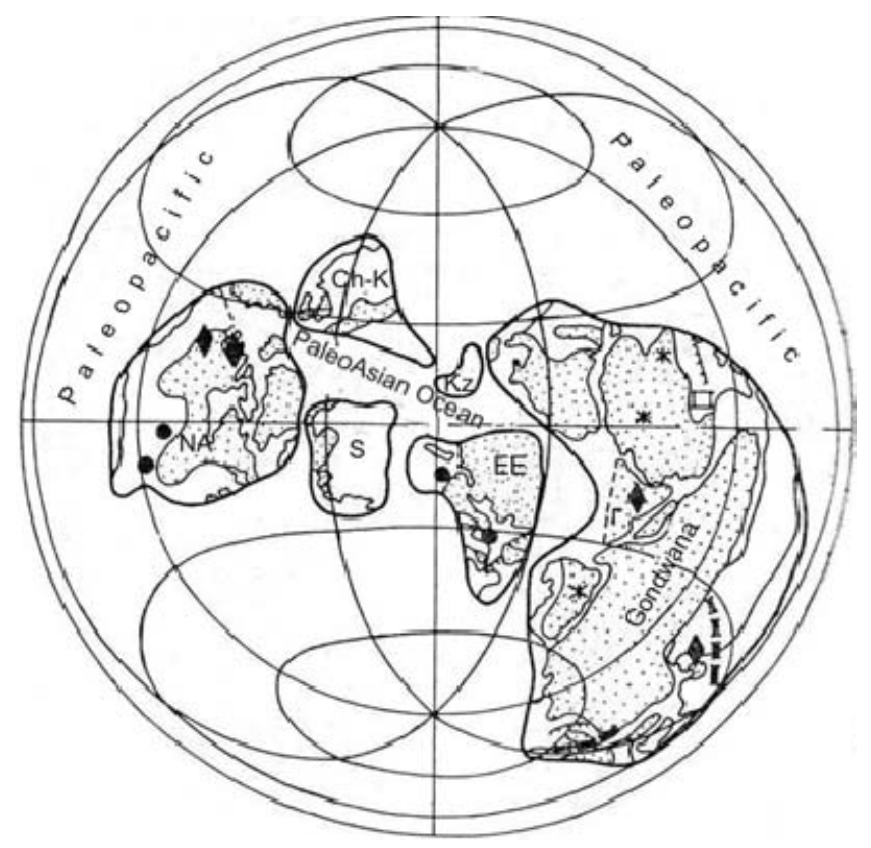

Early Silurian-Devonian Orogeny had completed the consolidation of the greater part of Kazakhstan with the exception of Zhongar-Balkhash basin, the northern Tien-Shan and Altai-Sayan-Mongolian region. It is also significantly affected the neighboring Baikal mountain region in the northeast and even had caused a deformation of the sedimentary cover in the southern part of the Siberian Craton. Tuva-Mongolia, Barguzin-Vitimsky and Central Mongolian micro-continents finally attached with the Siberian continent.

In the rest of the area, the mobile belts continued to develop volcanic arcs, particularly in the Urals, and in Kazakhstan geosuture zones.

As a result of the Caledonian Orogeny, at the beginning of Devonian age, the situation on the sphere had been changed markedly. In the Early Devonian, the uplifting of mountainous 
structures was continued in Kazakhstan, Altai-Sayan-Mongolia and Baikal regions. A new element, at least in the Paleozoic, was the formation of the regional volcan-plutonic Andean-type belts in Kazakhstan, and clastic filling materials in the border of the Caledonides and Zhongar-Balkhash basin. The position of the Kazakh continent in the Devonian, according to [20] is shown in Fig. 3.

The Paleo-Asiatic Ocean divided the eastern part of the Kazakh continent into two basins. During Paleozoic, the Kazakh continent has experienced several phases of tectonic activity, not under the influence of the surrounding continents, but most likely under the dynamic impact of mantle plumes. New deformational compressions took place in the Middle of Devonian. They are related to Telbessian Orogeny that was marked in the Altai-Sayan region. From the east and south-east, the Kazakh continent was fringed with a powerful boundary of volcan-plutonic belt that separated it from Zhongar-Balkhash basin, which belongs to the southern branch of the PaleoAsiatic Ocean. Behind this belt, the submerged Teniz and Zhezkazgan depressions were filled by red-colored continental molasse.

Fig. 3. Kz-Kazakhstan; NA-North America

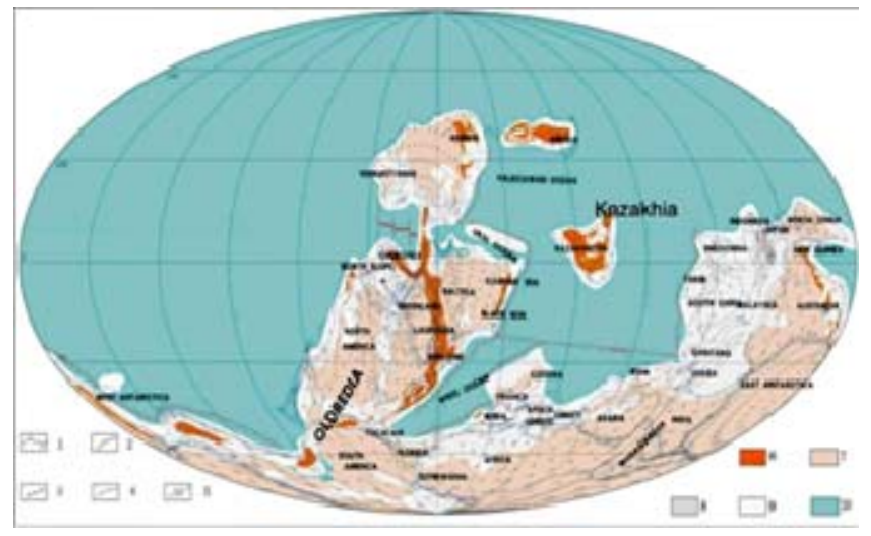

The general tectonic and the geographical situation in the Late Devonian was the moving a way of the largest continental blocks of the Eastern Hemisphere from each other's, where the juxtaposition of Lavrussii, Siberia, Kazakh and Tarim continents, has been changed. This led, at the beginning, to the reduction of the basins of the Paleo- Asiatic Ocean i.e. Ural, Turkestan (Tien Shan) and Mongolian basins. The numerous volcanic arc that emerged or continued their development in these basins, are located above the corresponding subduction zones.

During the Early Carboniferous was increased the promotion of Gondwana to the north and its convergence with Laurussia. Also Laurussia shifted to the north by turning in a clockwise direction and moved close to Siberia. This sharply reduced about $2.000 \mathrm{~km}$ of the width of the Paleo-Asiatic Ocean and in particular its Urals marginal basin. In the south, by the end of this era, a strong convergence of Kazakh continent with the edge of the East European continent, took place. In the Kazakh geosuture areas also emerged volcanplutonic belt.

Roman and Chinese-Korean continents, which were located further to the east, have become closer to Siberia and Central Mongolia. This preceded the impending closure of the PaleoAsiatic Ocean.

The Late Carboniferous was marked by a convergence of continental masses, where the late Carboniferous witnessed the joining of Laurussia with the Kazakh continent and its northern burying under the Western Siberia. Now they are separated by only a narrow fore-basin filled with flysch or molasse. They were accompanied by powerful new orogenic belt (UralSouthern Tien Shan-Zhongaria). Their formation is accompanied by the introduction of large plutons of granitoids. The main impulses of compression come at the end of EarlyMiddle Carboniferous (Sudetenland era, which proceeded within the Visean - Saur) and in Middle to Late Carboniferous (the era of Consumption). In the end of the orogeny was formed inter-mountains molasse depression.

Kazakh and Siberian-Mongolian continents were bordered by volcan-plutonic belts, which witness the ongoing subduction of the adjacent oceanic basins beneath their crusts. Kazakhstan denudation plain formed the western limit of the Ural basin, which is connected to the south with Turan oceanic Plate. At times, the coastal swampy lowlands accumulated coal-bearing strata. In Teniz-Shu Trench the water salinity became high and causing the precipitation of anhydrite, gypsum, and sometimes salt. In the south-eastern mountainous part of the Kazakh continent acidic and basic lava were erupted.

In Zhongar-Balkhash region and other regions of the Central Asia, active volcanoes took place. Uplifting was accompanied by an active volcanism, strong metamorphism and tectonic deformation. Inter-mountainous depressions were occupied with connected seas. At Tarim uplifting was prevailing, such as Sino-Korean, which was at a considerable distance from the Kazakh and Siberia continent, respectively.

By the beginning of the Permian period, the interlocking of Laurussia with Siberia was completed forming the Laurasia continent and the interlocking of Laurasia with Gondwana formed the Pangea II. In the Gondwana, from the Panthalassa side (Paleo-Pacific), a wide bay appeared and preserved the eastern part of Paleo-Tethys. Attached to the northern part of this bay Laurasia side, Roman, Chinese -Korean, South China and Indochinese merged with the last continent (South China) but closer to the southern, the Gondwana (Central Iranian, Central Afghan an and Tibetan continents).

During the collision of Eastern Europe, Kazakhstan and Siberia, high mountains including the Ural, Tien Shan, Kazakh plateau, Zhongaria, Altai and Sayan (Ural-Mongolian belt) were arisen and continued east across the northern and central Mongolia and Transbaikalian Dongbei (Ural-Okhotsk belt). These mountains are bordered on the west by Pre-Ural basin, while to the south by a severe volcan-plutonic belt, and extending over Paleo-Tethys oceanic crust - subduction zone.

In the Early Permian was the joining of the Siberian platform with Laurussia. Between them were the mountain 
structures of the Urals and elongated inter-mountain and piedmont basins occupied by aqueous bodies.

Laurasia supercontinent was flanked by large mountains and ridges that have arisen in the collision point of major and minor tectonic plates. In addition to the Ural Mountains that extend from new land to Kazakhstan. Mountain ranges have arisen in the Tien Shan, Zhongaria, the Altai-Sayan region and Mongolia. Inter-mountain depressions were occupied with outflow or poorly-flowing pools of variable salinity. In the Central Kazakhstan there was a large closed basin with high salinity. The thickness of evaporites and high-magnesium limestone with an admixture of terrigenous material is often more than $1 \mathrm{~km}$.

In the Jurassic, Central Asia and Kazakhstan continued to rise and inter-mountains basins within them, sometimes, were intensively submerged. The highest intensity they achieved was in Afghanistan and Central Pamir, where the collision of the Iranian-Afghanian continent with the southern edge of Laurasia - Kazakh, took place. Further to the east end of the folding of the Jurassic, which received the title of Europe's lateCimmerian is also manifested in central Tibet, where approaching and then collision of the South and North-Tibetan continental blocks, and the south-east Asian continent.

In the Cretaceous, the Tethys spreading was ceased, but in the back of the volcanic arc reveals the Black Sea basin, and to the east, possibly, the South Caspian. The uplifting of the Central Kazakhstan and Central Asia was continued but the rate of rising is significantly reduced. In the Turgay channel, which connects the Western Siberian Sea to the southern basin, terrigenous sediments were deposited, in the coastal area oolitic iron ores were deposited and bauxite rocks in the coastal lowlands. The development of the area of continental and coastal marine sediments was continued to the North of PreAral Sea, and enveloping the western shore of Kazakhstan, was extended in the Fergana Basin. In the vast sea shallow basins Turan plate was deposited carbonate-terrigenous sediments with phosphorites. From the south-west of the KazakhstanCentral Asian territory, a big depression was appeared, in which were accumulated gypsiferous lagoon, and purely continental red-carbonate sandy-clayey sediments.

Eocene transgression is most felt in the South East Europe, in the Trans-Caspian (Turan) and Western Siberia. A large part of Asia, from Central Kazakhstan to the Chukchi Peninsula remained, as in the Paleocene, but with some separated depressions occupied by lakes. In the Late Eocene, during the development of Tethys, significant fractures were developed. In the east, a collision of Hindustan fragments of Gondwana with the southern edge of Eurasia, took place, where marine basins were closed and the formation of the Himalayas was started. Kazakhstan, Central and Southern Siberia and Mongolia, in the early period displayed low denudation plains, but by the end of the era were uplifted. In the Oligocene Orogeny wave caused by the collision of the Indian subcontinent with Eurasia, begins to spread along Central Asia, including the Hindu Kush, Pamir and Tien Shan.

The Late Miocene witnessed a sharp increase in the speed of thrusts and shearing of mountainous ranges in the Alpine-
Himalayan and Central Asian belts. In this time, the main growth of these structures was occurred. At their periphery, in some advanced and inter-mountainous basins folding and thrusting were continued, in particular in the basins of the Tien Shan and others.

\section{CONCLUSION}

The ring structures of Kazakhstan are also reflected in the physical fields, particularly in the gravitational field. Also a clear display of the current block structure of the crust of Kazakhstan is discovered. Extended, linearly elongated strips of contiguous isanomal (large gradients) of the field $\Delta \mathrm{g}$ allocate deep zone: the faults separating the crust into a number of Kazakhstan megablocks and blocks. The most significant of them, according to geophysical data, cut the crust for all its power, and penetrate into the upper mantle $[8,9]$.

Among these deep fault zones, the most dramatically are displayed in the physical fields which attributed to sublatitudinal zones: North Tien Shan, Tekturma and Bektauatin; submeridional: Habarnin-Daulsk (West Mugalzhar), East Ulytau, Omsk-Tselinograd and Central Kazakhstan; northwest trend: the Main Karatau, Zhalair, Akbastau, Zhongar and Irtysh; northeast trend: Sevastopol (Ural-Tien-Shan shear zone), etc. [1].

Such structures are formed in the early stages of development of the territory and acquired a modern appearance in the form of Ural-Mongolian belt in the Mesozoic-Cenozoic. In the Cenozoic, the lineaments and partially dissecting ring structure zone are formed.

\section{REFERENCES}

[1] Geotectonicheskoe raionirovanie Kazakhstana po geophyzicheskim dannym, Moscow, Nedra, 1969, 512 p. (in Russian).

[2] Glubinnoe stroenie i minerallnye resursy Kazakhstana, vol. 1, Glubinnoe stroenie i geodinamica, Almaty, 2002. (in Russian).

[3] S.SH. Daukeev, B.S.Ushkenov, V.N. Lubezhkiy Evolutsia Zemli i protseccy formirovania mestoroshdeniy, Geologia Kazakhstana, Almaty, 2004. (in Russian).

[4] Tectonicheskaia carta Kazakhstana, Obiasnitellnaia zapiska, V.IA. Koshkin i dr., Almaty, 2007, 130 p. (in Russian).

[5] T.N. Cheraskov, V.A. Bush, A.N. Didenko, S.G. Samygin, Raspad Rodinii i rannie stadii razvitia Paleoasiatskogo okeana, Geotectonica, Mocow, 2010, vol. 1, pp. 5-28. (in Russian).

[6] N.L. Dobretsov, A.G. Kirdiashkin, A.A. Kirdiashkin Glubinnia geodinamica, Novosibirsk, SO RAN, 2001, 409 p. (in Russian).

[7] J. Golonka, M. Krobicki, N. Pajak, W. Zuchiewicz, Global plate tectonics and paleogeography of southeast Asia, Krakow, 2006, pp. 128.

[8] A.A. Abdulin, Geologia Kazakhstana, Alma-Ata, Nauka, 1981, 312 p. (in Russian).

[9] Atlas litilogo-paleogeographicheskich, structurnych, palinspasticheskich i geoekologicheskich cart Centallnoy Eyrasii, Almaty, 2002, 26 p. (in Russian).

[10] A.B. Baibatsha, O novom vzgliade na geologycheskoe stroenie i geodinamicheskoe razvitie terrirorii Kazakhstan, Izv. NAN RK, seria geol., Almaty, 2008, vol. 2., pp. 66-74 (in Russian). 